ISSN 1027-5495. Functional Materials, 25, No.2 (2018), p. 282-288

\title{
Effects of metal ion-doping on the characteristics and photocatalytic activities of $\mathrm{TiO}_{2}$ nanotubes
}

\author{
Shaona Wang, Rongfang Yuan, Beihai Zhou, Huanhuan Guan \\ Beijing Key Laboratory of Resource-oriented Treatment of Industrial \\ Pollutants, Department of Environment Engineering, School of Civil and \\ Environmental Engineering, University of Science and Technology Beijing, \\ Beijing 100083
}

\section{Received January 25, 2018}

Ion-doped $\mathrm{TiO}_{2}$ nanotubes were synthesized via a hydrothermal method and characterized by transmission electron microscopy, X-ray diffraction, X-ray photoelectron spectroscopy and specific surface areas. The binding energies of $\mathrm{Cu}^{2+}, \mathrm{V}^{2+}$, and $\mathrm{Zn}^{2+}$ indicated that the doping ions existed as $\mathrm{Cu}^{2+}, \mathrm{V}^{5+}$, and $\mathrm{Zn}^{2+}$, respectively. With the increase of the calcination temperature, the intensity of the anatase phase decreased and the BET surface area decreased. The extent of anatase phase increased with the increasing the calcination temperature, and then decreased. The highest catalytic activity for the un-doped $\mathrm{TiO}_{2}$ nanotubes was observed at a calcination temperature of $500^{\circ} \mathrm{C}$, with a Rhodamine B (RB) removal efficiency of $98.1 \%$. The removal efficiency of $\mathrm{RB}$ was $98.2 \%$ when $\mathrm{Cu}^{2+}$-doped catalyst calcined at $450{ }^{\circ} \mathrm{C}$ was added, $0.1 \%$ higher than the un-doped $\mathrm{TiO}_{2}$ nanotubes. The highest photocatalytic activity was obtained in the presence of $\mathrm{Zn}^{2+}$-doped catalyst calcined at $550{ }^{\circ} \mathrm{C}$, where $98.7 \%$ of $\mathrm{RB}$ was removed.

Keywords: nanotubes; metal ions-doped; Rhodamine B; photocatalytic oxidation

Методом электронной микроскопии, рентгеновской дифракции, рентгеновской фотоэлектронной спектроскопии изучены ионо-легированные нанотрубки $\mathrm{TiO}_{2}$ синтезированные гидротермическим методом .Энергии связи $\mathrm{Cu}^{2+}, \mathrm{V}^{2+}$ и $\mathrm{Zn}^{2+}$ показали, что легирующие ионы существуют как $\mathrm{Cu}^{2+}, \mathrm{V}^{5+}$ и $\mathrm{Zn}^{2+}$, соответственно. С увеличением температуры прокаливания интенсивность фразы анатаза уменьшалась и площадь поверхности по БЭТ уменьшалась. Степень фразы анатаза увеличивалась с увеличением температуры прокаливания, а затем уменьшалась. Наибольшая каталитическая активность для нелегированных нанотрубок $\mathrm{TiO}_{2}$ наблюдалась при температуре прокаливания $500{ }^{\circ} \mathrm{C} \mathrm{c}$ әфффективностью удаления Rhodamine B (RB) 98,1\%. Эфффективность удаления RB составляла $98,2 \%$, когда катализатор, легированный $\mathrm{Cu}^{2+}$, прокаленный при $450{ }^{\circ} \mathrm{C}$, был добавлен на $0,1 \%$ выше, чем не легированные нанотрубки $\mathrm{TiO}_{2}$. Наибольшая форокаталитическая активность получена в присутствии катализатора, легированного $\mathrm{Zn}^{2+}$, прокаленного при $550{ }^{\circ} \mathrm{C}$, где было удалено $98,7 \% \mathrm{RB}$.

Вплив іонного легування металів на характеристики i фотокаталітичні активності нанотрубок $\mathbf{T i O}_{2}$. Shaona Wang, Rongfang Yuan, Beihai Zhou, Huanhuan Guan

Методом електронної мікроскопії, рентгенівської дифракції, рентгенівської фотоелектронної спектроскопії вивчено іоно-леговані нанотрубки $\mathrm{TiO}_{2}$ синтезовані гідротермічним методом .Енергіі зв'язку $\mathrm{Cu}^{2+}, \mathrm{V}^{2+}$ i $\mathrm{Zn}^{2+}$ показали, що легуючі іони існують як $\mathrm{Cu}^{2+}, \mathrm{V}^{5+}$ і $\mathrm{Zn}^{2+}$, відповідно. Зі збільшенням температури прожарювання інтенсивність фази анатазу зменшувалася і площа поверхні по БЕТ зменшувалася. Ступінь фази анатазу збільшувалася зі збільшенням температури прожарювання, а потім зменшувалася. Найбільшу каталітична активність для нелегованих нанотрубок $\mathrm{TiO}_{2}$ спостерігалася при температурі прожарювання $500{ }^{\circ} \mathrm{C} 3$ ефективністю видалення Rhodamine B (RB) 98,1\%. Ефективність видалення RB становила 98,2\%, коли каталізатор, легований $\mathrm{Cu}^{2+}$, прожарений при $450^{\circ} \mathrm{C}$, був доданий на $0,1 \%$ вище, чим не леговані нанотрубки $\mathrm{TiO}_{2}$. Найбільша фотокаталітичну активність отримано у присутності каталізатора, легованого $\mathrm{Zn}^{2+}$, прожареного при $550{ }^{\circ} \mathrm{C}$, де видалено $98,7 \% \mathrm{RB}$. 


\section{Introduction}

Rhodamine B (RB) is a representative of xanthene cationic dyes and is known for its stability [1] It is harmful if swallowed and can cause irritation to the skin, eyes and respiratory tract. Photocatalytic oxidation is highly efficient in generating $\cdot \mathrm{OH}$ for the degradation of the pollutants [2].

The choice of photocatalysis is essential

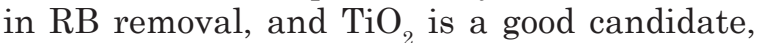
because $\mathrm{TiO}_{2}$-photocatalyzed reactions are non-selective oxidation processes at the level of micrograms per litre, and the use of $\mathrm{TiO}_{2}$ is effective for inactive substrates [3]. The photocatalytic performance of $\mathrm{TiO}_{2}$ depends on its crystal structure, particle size as well as effective surface area, and therefore with the use of nano-sized $\mathrm{TiO}_{2}$ the number of particles per unit area is increased enhancing its photocatalytic activity in the UV light [4,5]. Compared with its powder form, $\mathrm{TiO}_{2}$ nanotubes have a larger BET surface area $\left(S_{\mathrm{BET}}^{2}\right)$, which is advantageous in one-electron oxidation during photocatalytic reactions [6]. But, the relatively large bandgap of $\mathrm{TiO}_{2}(3.2 \mathrm{eV})$ limits the efficiency of photocatalytic reactions because of the high recombination rate of photogenerated electrons and holes [7]. Various attempts have been made to modify $\mathrm{TiO}_{2}$ to enhance its photocatalytic activity by coupling with other materials, such as semiconductor materials, metal ions [7], dyes and non-metal elements. These materials can form the energies of the intermediate states in the band gap. It is generally considered that the substitution for $\mathrm{Ti}^{4+}$ in the $\mathrm{TiO}_{2}$ lattice by certain metal ions creates impurity energy levels within the band gap, which may induce the activity of $\mathrm{TiO}_{2}$ [8] and act as electron trapper to inhibit the recombination of photo-generated electron-hole pairs [9]. Special attention has been recently focused on the investigation of the effect induced by transition metal dopants on the physicochemical properties of $\mathrm{TiO}_{2}$ and on the consequent change in photoactivity.

In this study, we investigated the effect of metal ion-doping on the photocatalytic activity of $\mathrm{TiO}_{2}$ nanotubes for RB removal via the UV/ $\mathrm{TiO}_{2}$ method. Three types of metal ions, namely, $\mathrm{Cu}^{2+}, \mathrm{V}^{5+}$, and $\mathrm{Zn}^{2+}$, were investigated, and $\mathrm{Zn}^{2+}$ was observed to be the optimum ion type. Analyses of the $\mathrm{TiO}_{2}$ nanotubes were conducted to determine the factors that affect the photocatalytic activities of the catalysts.

\section{Materials and methods}

\subsection{Materials}

P-25 $\mathrm{TiO}_{2}$ was provided by the Degussa Corporation (Richfield Park, New Jersey). The powder has an $S_{B E T}$ of $50 \mathrm{~m}^{2} \cdot \mathrm{g}^{-1}$, an average crystallite size of $21 \mathrm{~nm}$, and a crystal structure of $80 \%$ anatase and $20 \%$ rutile. RB (A.R.) was purchased from Beijing Chemical Reagent Company.

A photocatalytic reactor $(60 \mathrm{~mm}$ diameter and $750 \mathrm{~mm}$ length), which was equipped with a $37 \mathrm{~W} 254 \mathrm{~nm}$ UV lamp (15 mm Dia. and 793 mm Lth.) purchased from Haili Lighting Equipment Company (Beijing), was used in this experiment. $\mathrm{O}_{2}$ was generated by an oxygenator (Yao, Beijing), and was guided into the photocatalytic reactor through the bottom port. The samples were acquired from the sampling port in the middle of the reactor.

\subsection{Preparation of $\mathrm{TiO}_{2}$ nanotubes}

One gram of P-25 $\mathrm{TiO}_{2}$ was added to 16 $\mathrm{mL}$ of a $10 \mathrm{~mol} \mathrm{~L}^{-1} \mathrm{NaOH}$ aqueous solution in a Teflon vessel. The mixture was then stirred for $2 \mathrm{~h}$ at room temperature. The mixture was then heated at $110^{\circ} \mathrm{C}$ for $24 \mathrm{~h}$ in an oven, and cooled to room temperature in air. The as-prepared precipitate $\left(\mathrm{Na}_{2} \mathrm{Ti}_{3} \mathrm{O}_{7}\right)$ was washed with distilled water to achieve a $\mathrm{pH}$ of 7 and then subsequently dispersed in a $0.1 \mathrm{~mol} \cdot \mathrm{L}^{-1} \mathrm{HCl}$ aqueous solution. After ultrasonication for 30 min, the precipitate was continuously washed to achieve a pH of 7 and then dried at $60^{\circ} \mathrm{C}$. The nanotubes were prepared by calcining the precipitate at corresponding temperatures $\left(450{ }^{\circ} \mathrm{C}, 500^{\circ} \mathrm{C}, 550{ }^{\circ} \mathrm{C}\right.$, and $600^{\circ} \mathrm{C}$ ) for $2 \mathrm{~h}$.

The ion-doped $\mathrm{TiO}_{2}$ nanotubes were prepared using the aforementioned process in the presence of added metal salts to obtain a doping level of about $1.0 \%$. The following metal salts were used as precursors for dopant ions: $\mathrm{CuCl}_{2} \cdot 2 \mathrm{H}_{2} \mathrm{O}, \mathrm{NH}_{4} \mathrm{VO}_{3}$, and $\mathrm{ZnCl}_{2}$. The corresponding amounts added to the $10 \mathrm{~mol} \mathrm{~L}^{-1}$ $\mathrm{NaOH}$ solution were $0.0213,0.0146$, and 0.0170 $\mathrm{g}$, respectively. All dopant concentrations mentioned in this study are the nominal atomic values based on the assumption of quantitative dopant incorporation.

\subsection{Characterization of $\mathrm{TiO}_{2}$ nanotubes}

$\mathrm{X}$-ray diffraction (XRD) patterns were collected using a Rigaku Dmax-RB diffractometer (Tokyo, Japan). The surface elemental composition of $\mathrm{TiO}_{2}$ was recorded via X-ray photoelectron spectroscopy (XPS, AXIS ULTRA ${ }^{\text {DLD }}$, Kratos Analytical, UK). Transmission electron microscopy (TEM) images were obtained using a HITACHI HT-7700 electron microscope (Tokyo, Japan). $\mathrm{S}_{\mathrm{BET}}$ was measured using the Quadrasorb SI-MP apparatus (Quantachrome Instrument, USA). Diffuse reflectance spectroscopy (DRS) analyses were performed using a HITACHI U-3010 UV-vis scanning spectrophotometer (Tokyo, Japan). 
Table1. Catalytic properties of the $\mathrm{TiO}_{2}$ nanotube samples.

\begin{tabular}{|c|c|c|c|c|c|c|c|c|c|c|c|c|}
\hline \multirow{2}{*}{$\begin{array}{c}\text { Calcination } \\
\text { temperature } \\
{ }^{\circ} \mathrm{C}\end{array}$} & \multicolumn{4}{|c|}{$\begin{array}{l}\text { Weight fractions of anatase } \\
\text { phase (\%) }\end{array}$} & \multicolumn{4}{|c|}{$\begin{array}{l}\text { Indirect energy band gap/ } \\
(\mathrm{eV})\end{array}$} & \multicolumn{4}{|c|}{ BET surface areas $/\left(\mathrm{m}^{2} \cdot \mathrm{g}^{-1}\right)$} \\
\hline & 450 & 500 & 550 & 600 & 450 & 500 & 550 & 600 & 450 & 500 & 550 & 600 \\
\hline un-doped & 78.8 & 82.6 & 83.4 & 76.9 & 3.26 & 3.24 & 3.24 & 3.22 & 237 & 169 & 123 & 99 \\
\hline $\mathrm{Cu}^{2+}$-doped & 83.8 & 84.9 & 91.3 & 86.3 & 3.23 & 3.22 & 3.21 & 3.15 & 190 & 132 & 99 & 85 \\
\hline $\mathrm{V}^{5+}$-doped & 61.0 & 90.6 & 85.3 & 86.5 & 3.21 & 3.21 & 3.20 & 3.20 & 264 & 172 & 123 & 102 \\
\hline $\mathrm{Zn}^{2+}$-doped & 74.1 & 80.3 & 81.5 & 84.8 & 3.25 & 3.21 & 3.19 & 3.18 & 211 & 153 & 134 & 110 \\
\hline
\end{tabular}

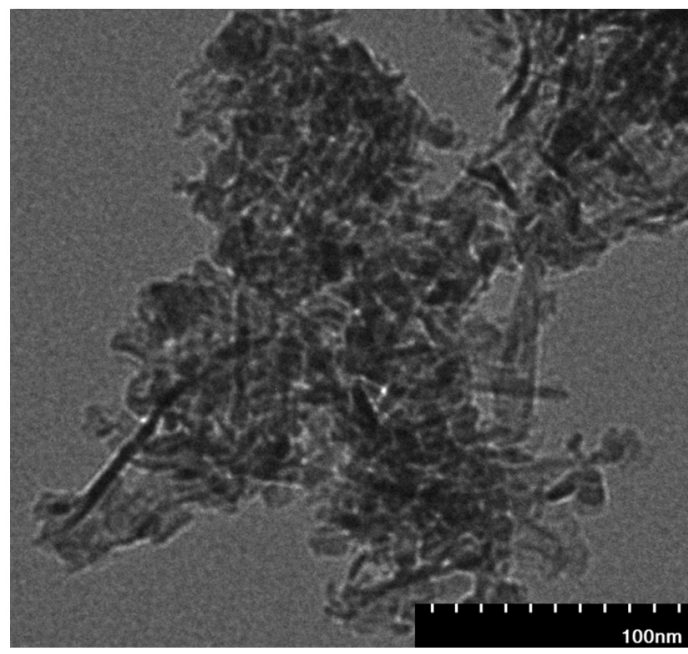

Fig. 1. TEM images of $\mathrm{Zn}^{2+}$-doped $\mathrm{TiO}_{2}$ nanotubes calcined at $550{ }^{\circ} \mathrm{C}$.

\subsection{Photocatalytic activity tests}

Aqueous slurries were prepared by adding

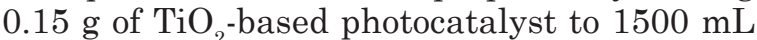
of $20 \mathrm{mg} \cdot \mathrm{L}^{-1} \mathrm{RB}$ aqueous solution at $\mathrm{pH}$ 7. The aqueous slurries were bubbled with $\mathrm{O}_{3}\left(1 \mathrm{~L} \cdot \mathrm{min}^{-1}\right)$ and irradiated with a $254 \mathrm{~nm}$ UV lamp. Every $10 \mathrm{~min}$, a $20 \mathrm{~mL}$ sample was acquired and centrifuged at $2000 \mathrm{rpm}$. The concentration of RB was determined using a UV-visible spectrophotometer (DR5000, Hach) at $500 \mathrm{~nm}$.

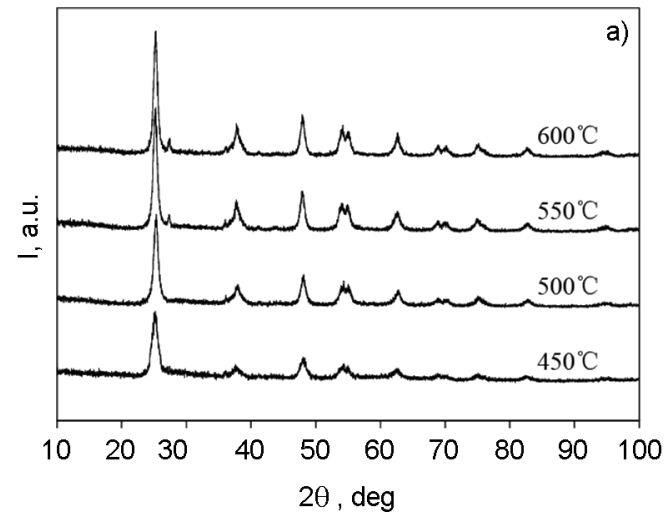

\section{Results and Discussion}

\subsection{Characterization of photocatalysts}

Transmission electron microscopy was performed to observe the morphology of the catalyst. Figure 1 shows the morphologies of $\mathrm{Zn}^{2+}$ doped $\mathrm{TiO}_{2}$ nanotubes calcined at $550^{\circ} \mathrm{C}$. The $\mathrm{TiO}_{2}$ nanotube was successfully synthesized. Other ion-doped nanotubes shared a similar morphology.

Figures 2(a) and 2(b) show the XRD patterns of the un-doped and ion-doped $\mathrm{TiO}_{2}$ nanotubes, respectively. The weight fractions of anatase in the anatase-rutile mixtures in the samples were calculated using Eq.1 [10].

$$
f=\frac{1}{1+1.265 \frac{I_{R}}{I_{A}}}
$$

Where $f$ is the weight fractions of anatase in the mixtures, and $I_{R}$ and $I_{A}$ are the maximum $\mathrm{X}$-ray diffraction peak intensities of rutile phase (110) and anatase phase (101), respectively. Table 1 lists the weight fractions of anatase in various samples.

Fig. 2 and Table 1 show that both anatase and rutile phases existed in the $\mathrm{TiO}_{2}$ nanotubes. The characteristic peaks of the (101) crystal plane of anatase and the (110) crystal

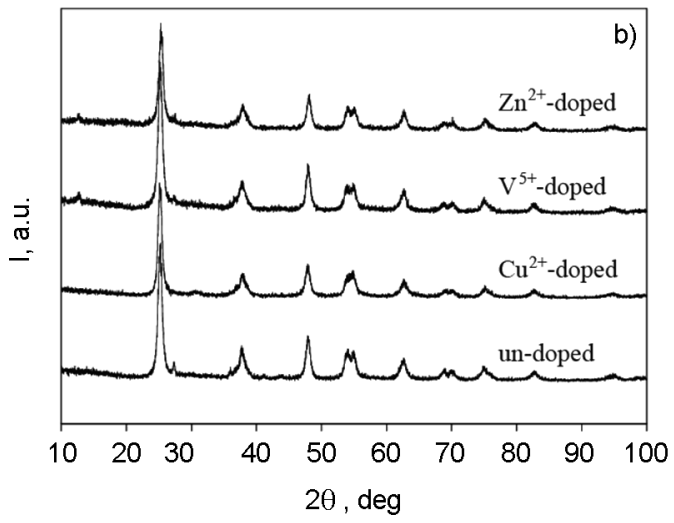

Fig. 2 . XRD patterns of the $\mathrm{TiO}_{2}$ nanotubes. (a) un-doped $\mathrm{TiO}_{2}$; (b) ion-doped $\mathrm{TiO}_{2}$ with different doped ions calcined at $550^{\circ} \mathrm{C}$. 

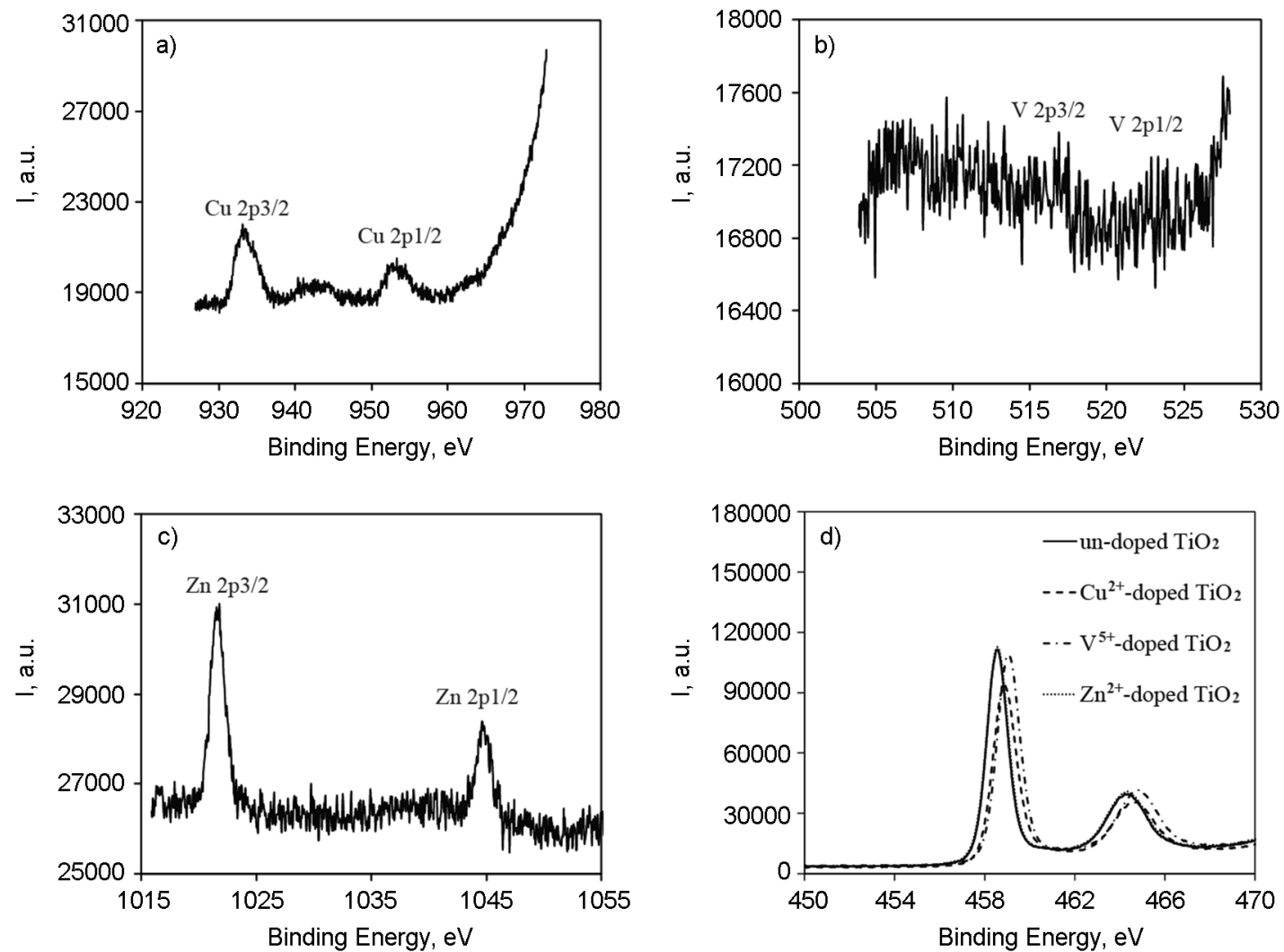

Fig. 3. XPS spectra of the $\mathrm{TiO}_{2}$ nanotubes: (a) $\mathrm{Cu}^{2+}$;

plane of rutile were located at about $25.3^{\circ}$ and $27.4^{\circ}$, respectively. When the calcination temperature was increased, the intensity of the anatase phase decreased, whereas that of the rutile phase increased. Compared with those of un-doped $\mathrm{TiO}_{2}$, the Bragg angles of the (101) peak position of the ion-doped $\mathrm{TiO}_{2}$ shifted to lower angles $(25.34,25.18,25.16$ and 25.26 for un-doped, $\mathrm{Cu}^{2+}$-doped, $\mathrm{V}^{5+}$-doped and $\mathrm{Zn}^{2+}$ doped $\mathrm{TiO}_{2}$, respectively), and the anatase peak intensity decreased. These results occurred because the crystallite had numerous crystal planes caused by ion doping; thus, such crystallite could not be considered as an ideal crystal. Furthermore, the dopant ions could substitute $\mathrm{Ti}^{4+}$ in the $\mathrm{TiO}_{2}$ nanotubes lattice, which resulted in the deformation of the crystal lattice. As a result, a broadening diffraction peak and a decreasing peak intensity were observed.

Some ions were partially dispersed in the bulk of $\mathrm{TiO}_{2}$ nanotubes [11]. The metallic oxides from other doped ions might also be formed on the surface of $\mathrm{TiO}_{2}$. These oxides were not observed in the XRD patterns because their metal sites (0.5-2.0 wt.\%) were expected to be below the visibility limit of X-ray analysis [12].

The XPS analysis was performed to determine the surface composition and the chemical state of the elements in the ion-doped $\mathrm{TiO}_{2}$ (b) $\mathrm{V}^{2+}$; (c) $\mathrm{Zn}^{2+}$; (d) $\mathrm{Ti}^{2+}$.

nanotubes calcined at $550{ }^{\circ} \mathrm{C}$ (Fig. 3a). The binding energies of $\mathrm{Cu}^{2+}, \mathrm{V}^{2+}$, and $\mathrm{Zn}^{2+}$ indicate that the doping ions existed as $\mathrm{Cu}^{2+}, \mathrm{V}^{5+}$, and $\mathrm{Zn}^{2+}$ in the $\mathrm{TiO}_{2}$ crystal lattice.

Fig. 3d shows that binding energies of $458.15 \mathrm{eV}$ to $459.00 \mathrm{eV}$ for $\mathrm{TiO}_{2}$ nanotubes correspond to the peaks of $\mathrm{Ti}^{2+} 3 / 2$, whereas binding energies of $464.05 \mathrm{eV}$ to $464.90 \mathrm{eV}$ correspond to $\mathrm{Ti}^{2+} 1 / 2$. The binding energy of $\mathrm{Ti}^{2+}$ indicates that $\mathrm{Ti}$ was incorporated into the lattice of $\mathrm{TiO}_{2}$ as $\mathrm{Ti}^{4+}$. When additional ions are introduced into the lattice, interaction between the outer-shell orbitals of these ions and the energy states in the bands creates impurity levels and changes the band structures. The $\mathrm{Ti}^{2+}$ binding energy of the ion-doped $\mathrm{TiO}_{2}$ nanotubes increased compared with that of pure $\mathrm{TiO}_{2}$ because the electrons in the conduction band of $\mathrm{TiO}_{2}$ are transferred to the doped metal ions on the surface of $\mathrm{TiO}_{2}$, which resulted in a decrease in the outer electron cloud density of Ti ions [13]. The ions, which have high oxidation states, decrease the energy of both the valence band maximum and the conduction band minimum because more oxygen ions are needed for charge compensation. The high occupancy of $d$-orbitals lowers the energy of the $d$ states, thus moving the energy levels away from the conduction band and contributing to the valence band maximum [14]. 
Table 2. The first order kinetics equation fitting of the $\mathrm{TiO}_{2}$ nanotube samples

\begin{tabular}{|c|c|c|c|}
\hline \multicolumn{2}{|c|}{ Parameter } & Equation & $\mathrm{R} 2$ \\
\hline \multirow{4}{*}{$\mathrm{Cu}$-doped $\mathrm{TiO}_{2}$} & $450^{\circ} \mathrm{C}$ & $\mathrm{Y}=15.093 \ln (\mathrm{x})+43.558$ & 0.7914 \\
\hline & $500^{\circ} \mathrm{C}$ & $\mathrm{Y}=18.595 \ln (\mathrm{x})+29.265$ & 0.8439 \\
\hline & $550^{\circ} \mathrm{C}$ & $\mathrm{Y}=22.217 \ln (\mathrm{x})+15.158$ & 0.8449 \\
\hline & $600^{\circ} \mathrm{C}$ & $\mathrm{Y}=25.7 \ln (\mathrm{x})+2.0518$ & 0.8732 \\
\hline \multirow{4}{*}{ Zn-doped $\mathrm{TiO}_{2}$} & $450^{\circ} \mathrm{C}$ & $\mathrm{Y}=34.301 \ln (\mathrm{x})+7.4218$ & 0.8713 \\
\hline & $500^{\circ} \mathrm{C}$ & $\mathrm{Y}=20.472 \ln (\mathrm{x})+23.192$ & 0.838 \\
\hline & $550^{\circ} \mathrm{C}$ & $\mathrm{Y}=15.003 \ln (\mathrm{x})+43.851$ & 0.8402 \\
\hline & $600^{\circ} \mathrm{C}$ & $\mathrm{Y}=19.856 \ln (\mathrm{x})+25.673$ & 0.8508 \\
\hline \multirow{4}{*}{$\mathrm{V}$-doped $\mathrm{TiO}_{2}$} & $450^{\circ} \mathrm{C}$ & $\mathrm{Y}=21.114 \ln (\mathrm{x})+18.398$ & 0.8682 \\
\hline & $500^{\circ} \mathrm{C}$ & $\mathrm{Y}=16.391 \ln (\mathrm{x})+36.875$ & 0.8313 \\
\hline & $550^{\circ} \mathrm{C}$ & $\mathrm{Y}=13.319 \ln (\mathrm{x})+49.558$ & 0.8614 \\
\hline & $600^{\circ} \mathrm{C}$ & $\mathrm{Y}=16.05 \ln (\mathrm{x})+39.118$ & 0.8452 \\
\hline
\end{tabular}
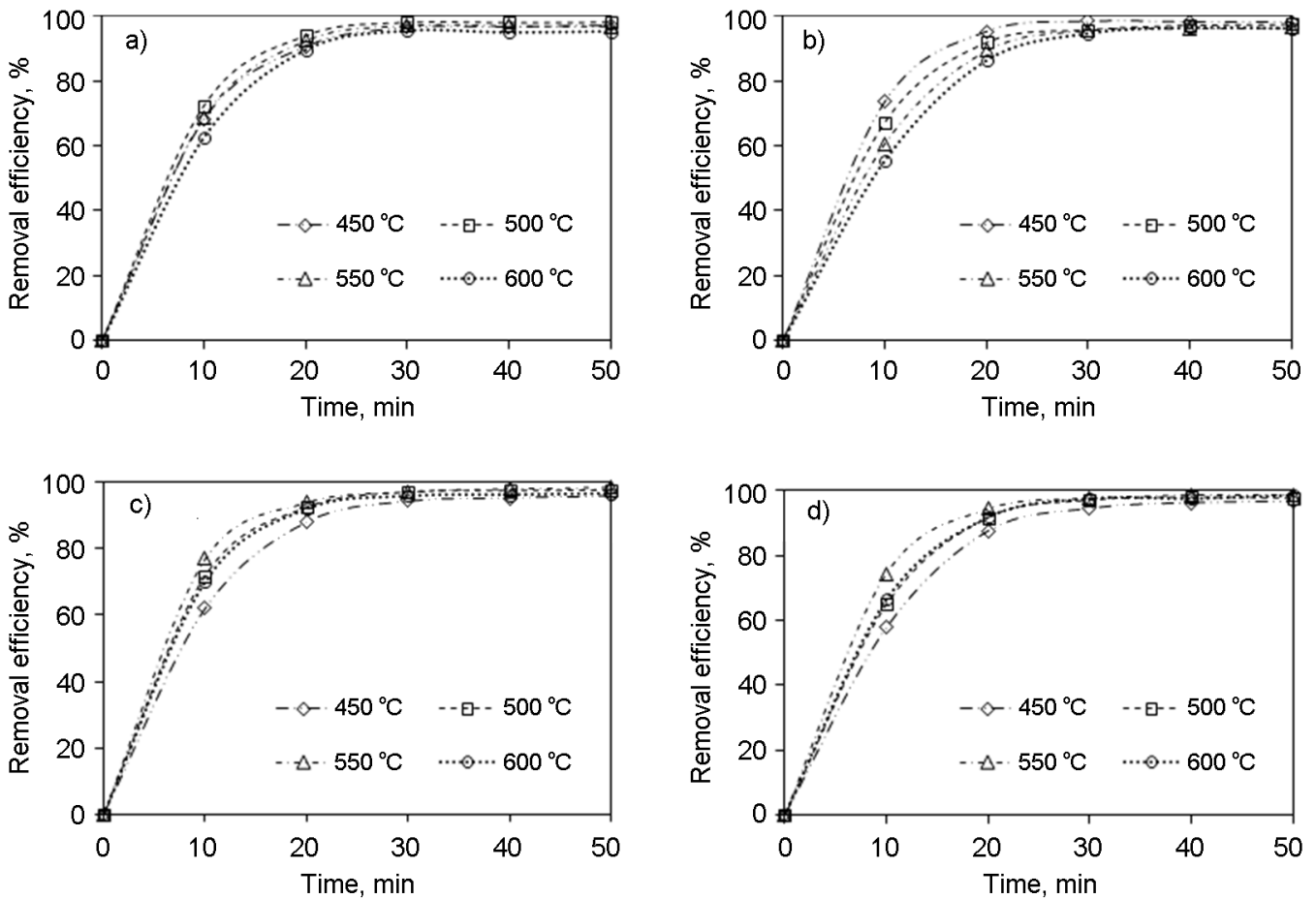

Fig. 4. Removal of $20 \mathrm{mg} \cdot \mathrm{L}^{-1} \mathrm{RB}$ in the presence: of different $\mathrm{TiO}_{2}$ nanotubes (a) un-doped $\mathrm{TiO}_{2}$; (b) $\mathrm{Cu}^{2+}$-doped $\mathrm{TiO}_{2}$; (c) $\mathrm{V}^{5+}$-doped $\mathrm{TiO}_{2}$; (d) $\mathrm{Zn}^{2+}$-doped $\mathrm{TiO}_{2}$.

The catalytic efficiencies of the $\mathrm{TiO}_{2}$ nanotubes are related to the $S_{B E T}$ of the catalyst [15]./ As summarized in Tabl. 1 , the $S_{B E T}$ of $\mathrm{TiO}_{2}$ nanotubes decreased with increasing calcination temperature. The decrease in $S_{B E T}$ could be attributed to the aggregation of nanotubes, which resulted in a closely coagulated structure [16]. The $S_{B E T}$ of ion-doped $\mathrm{TiO}_{2}$ nanotubes was smaller than that of un-doped $\mathrm{TiO}_{2}$ nanotubes. The $S_{B E T}$ decreased when metal ions were doped because of partial pore blockages and framework defects [11].

The $S_{B E T}$ of $\mathrm{TiO}_{2}$ nanotubes was significantly larger than that of $\mathrm{P}-25 \mathrm{TiO}_{2}$. This finding is attributed to the inner and outer surfaces of the layered-tubular structure, which is one of the special qualities of this catalyst [17].

The UV-vis DRS analysis was performed on the catalysts to obtain the energy band gaps $\left(E_{\mathrm{g}}\right) . \mathrm{TiO}_{2}$ nanotubes have an indirect band gap, and the plots relation was used:

$$
F\left(R_{\infty}\right) h \gamma=A\left(\mathrm{~h} \gamma-E_{g}\right)^{2}
$$

Where $F(R)$ is the Kubelka-Munk (K-M) function, $h$ is the Planck constant, and $\gamma$ is the frequency. The value of $F(R)$ can be estimated using the K-M formula: 


$$
F\left(R_{\infty}\right)=K / S=\frac{\left(1-R_{\infty}\right)^{2}}{2 R_{\infty}}
$$

Where $R_{\infty}$ is the diffuse reflectance. The plots of $E_{\mathrm{g}}$ were deduced from the intersection of the linear portion extrapolation with the energy axis. Table 1 shows the $E_{\mathrm{g}}$ of the catalysts.

The $E_{\mathrm{g}}$ decreased with increasing calcination temperature. This trend occurred because the $E_{\mathrm{o}}$ of rutile $\mathrm{TiO}_{2}(3.0 \mathrm{eV})$ was narrower than that of anatase $\mathrm{TiO}_{2}(3.2 \mathrm{eV})$, and the rutile phase of $\mathrm{TiO}_{2}$ began to form when the calcination temperature was increased. The $E_{\mathrm{o}}$ of undoped $\mathrm{TiO}_{2}$ nanotubes was between 3.30 and $3.22 \mathrm{eV}$, which was a little higher than that of anatase $\mathrm{TiO}_{2}$ in powder form. This shift was owing to the quantum size effect on different morphologies of the catalysts [18]. The reflectance spectra of ion-doped $\mathrm{TiO}_{2}$ slightly shifted toward a longer wavelength (red shift) compared with those of un-doped $\mathrm{TiO}_{2}$, and the $E_{\mathrm{g}}$ of ion-doped $\mathrm{TiO}_{2}$ was visibly narrower. The results show that the doped elements were indeed integrated into the lattice of the $\mathrm{TiO}_{2}$ nanotubes, thereby altering the crystal and electronic structures of the $\mathrm{TiO}_{2}$ nanotubes [17]. The reduction in $E_{\mathrm{o}}$ of the $\mathrm{TiO}_{2}$ nanotubes allows the excitation of the catalyst at a lower irradiation power. Thus, the photocatalytic activity of the catalyst is enhanced [19].

Photocatalytic activity tests were conducted to investigate the effects of morphology, calcination temperature, and the type of dopants on the catalytic activity of $\mathrm{TiO}_{2}$ nanotubes. As shown in Fig. 4, the highest catalytic activity for the un-doped $\mathrm{TiO}_{2}$ nanotubes was observed at a calcination temperature of $500{ }^{\circ} \mathrm{C}$, with an RB removal efficiency of $98.1 \%$. The $S_{B E T}$, crystalline phases, crystallinity, and $E_{\mathrm{o}}$ of $\mathrm{TiO}_{2}$ nanotubes were considered as crucial factors that affect the photocatalytic activity of the catalyst. When the calcination temperature was increased, the $S_{B E T}$ decreased (see Tabl. 1). The $S_{B E T}$ could affect the photocatalytic activities of the catalyst because a larger $S_{B E T}$ indicates that more pollutants are adsorbed onto the surface of the catalyst, and more areas become available for electron-hole pair separation. The anatase phase exhibited a higher photocatalytic activity compared with other phases [17]. Although the $S_{B E T}$ of $\mathrm{TiO}_{2}$ nanotubes calcined at $450{ }^{\circ} \mathrm{C}$ were larger, the crystalline phases were predominantly amorphous, which resulted in low photocatalytic activity, and broadened $E_{\text {. }}$ of $\mathrm{TiO}_{2}$. For $\mathrm{TiO}_{2}$ nanotubes calcined at 550 ${ }^{\circ} \mathrm{C}$, and $600{ }^{\circ} \mathrm{C}$, although the main crystalline phases were anatase, the amount of rutile phase increased, and the $S_{B E T}$ decreased; thus, the overall efficiencies were low.
The first order kinetics equation fitting models were developed to predict removal efficiency using variables (time) (Tabl. 2).

Photocatalytic activity was also affected by ionic radius, valence state, and configuration. The removal of RB increased when $\mathrm{Cu}^{2+}, \mathrm{V}^{5+}$, and $\mathrm{Zn}^{2+}$ were doped into the $\mathrm{TiO}_{2}$ nanotubes. The highest photocatalytic activity was obtained in the presence of $\mathrm{Zn}^{2+}$-doped catalyst calcined at $550^{\circ} \mathrm{C}$, where $98.7 \%$ of $\mathrm{RB}$ was removed. The catalytic activity was affected by the following factors. First, the existing impurity band can reduce the recombination of photoinduced electron-hole, which can transfer electrons more efficiently to the oxygen adsorbed on the surface of $\mathrm{TiO}_{2}$ nanotubes [20]. Second, the weight fractions of the anatase phases of the catalyst were larger than those of un-doped $\mathrm{TiO}_{2}$ nanotubes, the $E_{\mathrm{g}}$ of the nanotubes were narrower, and the $S_{B E T}$ of the catalyst were smaller. Third, the ionic radii of the doped ions affected the photocatalytic activities.

The ionic radii of $\mathrm{Cu}^{2+}$ and $\mathrm{Zn}^{2+}$, which were 73 and $74 \mathrm{pm}$, respectively, were slightly larger than that of $\mathrm{Ti}^{4+}$. $\mathrm{CuO}$ and $\mathrm{ZnO}$ might be formed on the surface of the $\mathrm{TiO}_{2}$. In the $\mathrm{TiO}_{2}$ semiconductors, the potential energy levels of the conduction and valance band of $\mathrm{TiO}_{2}$ and $\mathrm{ZnO}$ lie above the $\mathrm{CuOcb}$ and $\mathrm{CuOvb}$ levels. Accordingly, the ultraviolet irradiation induces both the $\mathrm{e}^{-}$transfer and $\mathrm{h}^{+}$transfer from $\mathrm{TiO}_{2}$ and $\mathrm{ZnO}$ to $\mathrm{CuO}$ [21]. The combination of $\mathrm{TiO}_{2}$ with the doped metallic oxide results in the generation of $\mathrm{Ti}^{3+}$. The electrons were transferred to $\mathrm{Ti}^{3+}$ and then to the oxygen, which could reduce the probability for recombination between electrons and holes. In addition, the photogenerated holes left in the valence band would have more opportunity to participate in the oxidizing reactions because photogenerated electrons can be effectively scavenged by $\mathrm{Cu}^{2+}$ and $\mathrm{Zn}^{2+}$ ions [22] Therefore, the removal efficiencies increased, with the RB removal efficiency of $98.2 \%$ and $98.7 \%$ in the presence of $450^{\circ} \mathrm{C}$ calcined $\mathrm{Cu}^{2+}$. doped and $550^{\circ} \mathrm{C}$ calcined $\mathrm{Zn}^{2+}$-doped $\mathrm{TiO}_{2}$.

Doping $\mathrm{TiO}_{2}$ with $\mathrm{V}^{5+}$, whose valence was higher than that of the parent $\mathrm{Ti}^{4+}$, resulted in an increase in the concentration of electrons in the conduction band. An upward shift of the Fermi energy level was also expected. When the dopant concentration was increased, the surface barrier became higher and the space charge region became narrower [23]. The electron-hole pairs photogenerated within this region were efficiently separated by the large electric field traversing the barrier before these pairs had the chance to recombine [24]. Therefore, the RB removal efficiency increased to be $98.6 \%$ when the calcination temperature was $550^{\circ} \mathrm{C}$. 


\section{Conclusions}

Ion-doped $\mathrm{TiO}_{2}$ nanotubes were successfully synthesized for $\mathrm{RB}$ removal. The ions were effectively incorporated into the $\mathrm{TiO}_{2}$ lattice. When the ions were doped and the calcination temperature was increased, the $S_{B F T}$ of $\mathrm{TiO}_{2}$ decreased, and the $E_{\sigma}$ of ion-doped $\mathrm{TiO}_{2}$ became visibly narrower. The photocatalytic activities of catalysts on $\mathrm{RB}$ removal could be increased when ions were doped into the $\mathrm{TiO}_{2}$ nanotubes. The $\mathrm{Zn}^{2+}$-doped $\mathrm{TiO}_{2}$ nanotubes had the highest catalytic activity because of the effects of the weight fractions of the anatase phase, $S_{B E T}, E_{\mathrm{g}}$, and the doped ions.

\section{References}

1. Sayılkan, F., Erdemoğlu, S., Asiltürk, M., et al Mater. Res. Bull., 41(12), 2276, 2006.

2. Lin, C., Lin, K.S., Chemosphere, 66, 1872, 2007.

3. Li, H., Wang, J., Li, H., Yin, S., Sato, T. , Res. Chem. Interm., 36(1), 27, 2010.

4. Bastakoti, B.P., Wu, K.C., Yamauchi, Y. J. Nanosci. Nanotechn., 13(4), 2735, 2013.

5. Oveisi, H., Suzuki, N., Beitollahi, A., Yamauchi, Y., J. Sol-Gel Scie. Techn., 56 (2), 212, 2010.

6. Tachikawa, T., Tojo, S., Fujitsuka, M., Toru Sekino, A., Majima, T., J. Phys. Chem. B, 110(29), 14055,2006

7. Sun, L., Li, J., Wang, C.L., Li, S.F., Chen, H.B., Lin, C.J., Lin C J., Solar Energy Mater. Solar Cells,, 93, 1875, 2009

8. Zhu, Y., Zhang, L., Yao, W., Cao, L., Appl. Surf. Scie., 158, 32, 2000.

9. Vásquez, G.C., Pecheherrero, M.A., Maestre, et al, J.Phys. Chem. C, 117(4), 1941, 2013.

10. Spurr, R.A., Myers, H., Anal. Chem., 29(5), 760, 1957.
11. Pang, Y.L., Abdullah, A.Z., J. Hazard. Mater. 235-236(2), 326, 2012.

12. Ravichandran, L., Selvam, K., Krishnakumar, B., Swaminathan, J. Hazard. Mater. 167(1), 763, 2009.

13. Chang, S.M., Liu, W.S., Appl. Catal. B Environment., 156-157, 466, 2014.

14. Li, X., Zou, X., Qu, Z., Zhao, Q., Wang, L., Chemosphere, 83(5), 674, 2011.

15. Gomes, Silvaalmeida, G.D., Dekosaka, A.T., Monteirorogero, P., Otacruz, S., SilveiraIkeda, á., Ichikawapetri, T., Siqueira, D.F. Mater. Res., 10(4), 469, 2007.

16. Zhang, G.W., He, G.H., Xue, W.L., Xu, X.F., Liu, D.N., Xu, Y.H.,, J, Mol,Catal, A Chem,, 363-364, 423, 2012.

17. Pang, Y.L., Abdullah, A.Z., Ultrasonics Sonochem., 19(3), 642, 2012.

18. Zhou, M., Yu, J., Liu, S., Zhai, P., Huang, Appl. Catal. B Environment., 89(1-2), 160, 2009.

19. Pang, Y.L., Abdullah, A.Z., Appl. Catal. B Environment.,129(3), 473, 2013.

20. Li, A., Zhao, X., Liu, H., Qu, J.,Water Res., 45(18), 6131, 2011.

21. Khaki, M.R.D., Sajjadi, B., Raman, A.A.A., Wan, M.A.W.D., Shmshirband, S., Measurement, 77, 155,2016

22. Zang, L., Liu, C.Y., Ren, X.M., J.Photochem. Photobiol. A Chem., 79(3), 189, 1994.

23. Hidalgo, J.M., Tišler, Z., Kubička, D., Raabova, K., Bulanek, R. , J. Molec. Catal. A Chem., 420, 178, 2016.

24. Habibi, M.H., Hassanzadeh, A., Mahdavi, S. J. Photochem.Photobiol. A Chem., 172(1), 89, 2005. 